\title{
At the intersection of material finds and identity
}

Tell Abu Sarbut is situated in the Jordan Valley about $80 \mathrm{~km}$ north to Amman, the excavation seasons 2012-2015 revealed a small Early Roman hamlet and unexpected and surprising stone vessels were found.

The vessels were hand cut or lathe turned, produced around Jerusalem and in Galilee in Capernaum, Sepphoris, Nabratein and also in Gamla in the Golan. Soft chalkstone vessels excavated from Levantine sites dated between $100 \mathrm{BC}$ and $200 \mathrm{AD}$, are always found together with specific oil lamps, pottery, and sometimes with stepped pools.

Such stone vessels are well known from Qumran and Jerusalem, they are considered markers of Jewish identity.

There is an on-going discussion on the subject. According to Berlin material possessions encode and reflect religious identity. (A.Berlin, 2005. Jewish Life Before the Revolt. Journal for the Study of Judaism 36, 4 :417470). Near contemporaneous texts tell that stone vessels were considered impervious to ritual impurity. Different authors state that the phenomenon is a uniquely Jewish one, because these utensils are conspicuously absent from non-Jewish sites.

Most of the finds are from Israel only a few were reported from Jordan. The limestone vessels form Tell Abu Sarbut rise the question if these artifacts can reveal the identity of the people once living in that tiny hamlet in the eastern Jordan Valley.

An important questions in my research on the material from Tell Abu Sarbut is: What are the conditions to link religious identity to archaeological structures and artifacts? The central question in this might be: Is it legitimate to link artifacts to ethnic groups? I would appreciate ideas and suggestions on both questions. 